\title{
Kuraklık Stresinin Urfa Biberinde İyon Klorofil ve Enzim İçerikleri Üzerine Etkisi**
}

\author{
Illyas YABAN ${ }^{1} \quad$ Turgay $\mathrm{KABAY}^{2, *}$
}

${ }^{2}$ Yüzüncü Yı Üniversitesi, Erciș Meslek Yüksekokulu, VAN

*Sorumlu yazar e-mail (Corresponding author e-mail): tkabay@yyu.edu.tr

Geliș tarihi (Received) : 09.09.2018

Kabul tarihi (Accepted): 26.02.2019

DOI : $10.21657 /$ topraksu. 544650

\section{Öz}

Urfa biberi farklı tüketim șekilleri ile ülkemiz için önemli iç tüketim ve ihraç ürünüdür. Ancak son yıllarda kurakıık nedeniyle Urfa biberinde verim ve kalite de azalma olmaktadır. Bu çalıșmada, kuraklık stresindeki Urfa biberinin $\mathrm{K}, \mathrm{Ca}, \mathrm{Mg}$, Klorofil içerikleri ile CAT, SOD ve APX aktivitelerinin kuraklık stresinden nasıl etkilendiğini tespit etmek amaçlanmıștır. Çalıșmada Șanlıurfa bölgesinde Gölpınar, Hilvan, Osmanbey genotipleri ile İnan 3363 standart biber çeșitleri kullanılmıștır. Biber tohumları, 1 litre hacminde toprak içeren plastik saksılara ve her saksıya iki adet tohum olacak șekilde ekilmiștir. Gerçek yapraklar çıktıktan sonra her saksıda bir bitki bırakıımıștır. Bitkiler 30 günlük fide durumundayken kuraklık uygulaması olan bitkilerde sulama kesilmiș ve 19 gün su verilmemiștir. Kontrol bitkilerinde ise intiyaca göre sulamaya devam edilmiștir. Çalıșmanın yürütüldüğü iklim odasının ortalama sıcaklık değeri gündüz $23^{\circ} \mathrm{C}$ ve gece $18^{\circ} \mathrm{C}$, Ișık șiddeti ise ortalama 8000 lüks olarak ölçülmüștür. Tesadüf parselleri deneme desenine göre üç tekerrürlü olarak dizayn edilen çalıșma sonucunda Gölpınar ve Hilvan genotipleri kuraklık stresine toleranslı çıkarken, İnan 3363 biber çeșidinin ise hassas olduğu belirlenmiștir.

Anahtar Kelimeler: Enzim, iyon, klorofil, kuraklık, Urfa biberi

*Yüksek lisans tezinden türetilmiștir.

\section{Effect of Drought Stress on Enzyme Chlorophyll and Ion Contents in Urfa Peppers}

\begin{abstract}
Urfa pepper which is different consumption pattern is a consumption and export product for our country. However, due to the drought in recent years, the yield and quality of Urfa pepper have decreased. In this study, it was aimed to determine the $\mathrm{K}, \mathrm{Ca}, \mathrm{Mg}$, chlorophyll contents and the changes in CAT, SOD and APX activities of Urfa pepper under drought stress. Gölpınar, Hilvan, Osmanbey genotypes used in Șanlıurfa region and İnan 3363 standard pepper varieties were used in the study. Pepper seeds were planted in plastic pots containing 1 liter of soil and two seeds were planted in each pot. After the cotyledon leaves emergence, one plant was left in every pot. When plants were 30 days old seedlings, irrigation was stopped and no water was given for 19 days to drought application plants. The irrigation were continued according to their needs in control plant. The average temperature of climate room in which the study was conducted was measured as $23^{\circ} \mathrm{C}$ in day time, $18^{\circ} \mathrm{C}$ in night time and the light intensity was measured as 8000 lux. At the end of study which dsayned according to the randomized experimental design, it was determined that Gölpınar and Hilvan genotypes were tolerant to drought stress, while pepper varieties of İnan 3363 were sensitive.
\end{abstract}

Key words: Enzyme, ion, chlorophyll, drought, Urfa pepper. 


\section{Giriș}

Kuraklık gibi abiyotik stresler bitkisel üretimde verim kaybının bașlıca nedenleridir. Kurak koșulların, hücrelerin bölünmesini ve büyümesini azaltıcı etkisi sonucunda bitki gelișiminin azalmasına ve ayrıca kuraklık sırasında büyüme için bir itici güç olan turgor basıncının azalmasına ve transpirasyonun olumsuz etkilenmesine, mineral madde alımının gerilemesine ve büyüme hızının düșmesine neden olabileceği vurgulanmıștır (Kabay vd. 2018a; Kabay 2019). Bu nedenle kuraklık, tarımsal üretim için en önemli sınırlayıcı faktörler arasında yer almaktadır (Liu ve Stützel, 2004; Özfidaner vd., 2018). Abiyotik streslerde reaktif oksijen türlerinin (ROS), bitkilerde strese karșı toleransın artırılmasında önemli rol oynadığı düșünülmektedir (Kabay 2018a; Kabay 2018b). Kuraklık stresi bitkilerde enzim aktivitesi ve enzim miktarı üzerine de önemli bir etki yapar. Ayrıca absisik asit miktarı yapraklarda 40 kat artıș gösterirken, kökte dahil olmak üzere diğer organlarda bu artıș daha azdır. Absisik asit stomaların kapanmasına neden olarak suyun transpirasyonunu engeller. Bitkinin üst organlarındaki gelișmeyi azaltarak suyun kökte kullanılmasına, kökün derinlere doğru inebilmesine ve daha fazla suya erișimine imkân sağlar. Yaprak sayısı ve alanın yanısıra bitki gövdesinde küçülmeler görülür (Kacar vd., 2006).

Kuraklık stresinin iki tatlı sorgum bitkisinde antioksidatif enzim sistemi üzerine etkisinin araștırıldığı çalıșmada, antioksidatif enzim aktivitesindeki artıșın kuraklığa toleransı arttırdığı belirtilmektedir (Guo vd., 2018). Domateste uygulanan su stresi, verim ve meyve kalitesinin düșmesine neden olurken, tolerant çeșitlerdeki antioksidant içeriğinin duyarlı çeșitlerden daha yüksek çıktığı vurgulanmıștır. (Sanchez Rodriguez vd., 2010; Alp ve Kabay, 2017). Domateste yapılan çalıșmada kuraklık ve tuzlu șartlarda bitki gelișiminin olumsuz etkilendiği ve bitkideki K ile Ca oranlarının azaldığı bildirilmektedir (Ali ve Rab, 2017). Biberde 20 genotip'e su stresinin uygulandığı çalıșmada kuraklık stresindeki genotiplerde klorofil içeriği, SOD ve CAT aktivitelerinde farklılıklar olduğu ve çalıșma sonunda kuraklığa dayanıklı, hassas ve orta derece dayanıklı olarak sınıflandırıldığı belirtilmektedir (Özkan vd. 2013; Sahitya vd., 2018). Kuraklık stresine karșı hassas ve dayanıklı anaçlar üzerine așllı sırık domates bitkilerinde yapılan çalıșmada dayanıklı anaç kullanımı ile bitki boyu, ortalama gövde çapı, yaprak alanı, bitki yaș ve kuru ağılıkları, toplam verim, pazarlanabilir verim, ortalama meyve ağırlığı, ortalama meyve büyüklüğü, klorofil ve karotenoid miktarı prolin miktarı, SOD, CAT, GR ve APX enzim aktivitesi değerleri de artıș olduğu belirtilmektedir (Altunlu, 2011). Kuraklık stresi uygulanan fasulye genotiplerinin MDA, CAT, SOD ve APX aktivitelerinde değișmeler meydana gelirken, $\mathrm{K}$ ve Ca değerleri kuraklığa hassas çeșitlerde daha düșük çımıș, kuraklığa tolerant genotiplerde ise kontrol bitkilerine yakın değerler saptanmıștır (Kabay ve Șensoy, 2016; Kabay ve Șensoy, 2017). Soyada (Glycine max L.CV., A3935), kuraklık stresi sonucu MDA aktivitesinin arttığı ve klorofil miktarının da azaldığı belirtilmiștir (Kayabașı, 2011 ).

Kuraklığa bağlı olarak șeftali yapraklarının fizyolojik, biyokimyasal ve moleküler tepkilerinin araștırıldığı çalıșmada, antioksidan enzimlerin aktivitelerinin kuraklıkla birlikte arttığı ve bitkilerde lipit peroksidasyonu ile fotosentez miktarında azalmalar olduğu belirtilmiștir (Haider vd. 2018). Fasulyede çeșitlerinde yüksek sıcaklık ve su streslerinin etkilerinin incelendiği çalıșmada, duyarlı çeșidin stresten olumsuz yönde etkilendiği, tolerant çeșidin ise kontrole yakın değerler verdiği belirlenmiștir (Gonzalez ve Pastenes, 2012).

Yaptığımız çalıșmada Șanlıurfa bölgesinde Gölpınar, Hilvan, Osmanbey genotipleri ile İnan 3363 standart biber çeșidinin kuraklık stresinde Klorofil, K, Ca, Mg içerikleri ile CAT, SOD; APX ve MDA aktivitelerindeki değișimlerinin belirlenmesi amaçlanmıștır.

\section{MATERYAL VE YÖNTEM}

Kuraklık stresi altında yetișen Urfa biberinin $\mathrm{K}, \mathrm{Ca}, \mathrm{Mg}$, klorofil içerikleri ile CAT, SOD ve APX aktivitelerinde meydana gelen değișimlerin incelendiği çalıșmada Șanlıurfa Bölgesine ait Gölpınar, Hilvan, Osmanbey biber genotipleri ile İnan 3363 standart biber çeșidi kullanılmıștır. Çalıșmada biber tohumları, 1 litre hacminde toprak içeren plastik saksılara, her saksıya iki adet tohum olacak șekilde ekilmiștir. Gerçek yapraklar çıktıktan sonra her saksıda bir bitki bırakılmıștır. Bitkiler 30 günlük fide durumundayken kuraklık uygulaması olan bitkilerde sulama kesilmiș ve 19 gün su verilmemiștir. Kontrol bitkilerinde ise intiyaca göre sulamaya devam edilmiștir. Çalıșmanın 
yürütüldüğü iklim odasının sıcaklık değeri gündüz ortalama $23{ }^{\circ} \mathrm{C}$ ve gece ise $18{ }^{\circ} \mathrm{C}$ ve Ișık șiddeti ise ortalama 8000 lüks olarak ölçülmüstür. Tesadüf parsellerinde faktöriyel deneme desenine göre üç tekerrürlü olarak dizayn edilen çalıșma sonucunda șu analizler yapılmıștır:

\section{Mineral element analizleri}

Kuraklık stresinin uygulandığı bitkiler ile kuraklık stresi uygulanmayan kontrol bitkilerinden iki bitki alınıp bitkinin tümü önce açıkta daha sonra 65 ${ }^{\circ} C^{\prime}$ de 48 saat etüvde kurutulduktan sonra $0.5 \mathrm{~g}$ yeșil aksamdan alınıp mineral madde tayini için kullanılmıștır. 0.5 gtartılan kurutulmuș ve öğütülmüș bitki örnekleri etil alkolle ön yakma yapıldıktan sonra $550{ }^{\circ} \mathrm{C}$ kül fırınında kül olușuncaya kadar yakılmıștır. Elde edilen kül, \% 3.3'lük HCl'de çözünmüș ve mavi bantlı filtre kağıdında süzüldükten sonra K, Ca, Mg, okumaları Yüzüncü Yıl Üniversitesi Bilimsel Araștırma ve Uygulama Merkezinde atomik absorbsiyon cihazında yapılmıștır (Bağcı, 2010; Kușvuran, 2010; Kabay ve Șensoy 2016; Kabay ve Sensoy 2017).

\section{Klorofil miktarı}

Biber bitkilerinde, alttan üçüncü yapraktan alınan $0.25 \mathrm{~g}$ örnekler, doğrudan ıșık gelmeyen loș bir yerde \% 80' lik aseton içerisinde homojenize edilip, filtre edildikten sonra ekstrakt aseton ile 25 ml' ye tamamlanmıștır. Hazırlanmıș örnekler $663 \mathrm{~nm}$ ve $645 \mathrm{~nm}$ dalga boyunda okunup așağıda verilen formül yardımıyla hesaplanmıștır (Lichtenthaler ve Wellburn 1983; Zengin 2007; Amira ve Oados 2011 ; Zushi vd. 2012).

Klorofil a $(\mathrm{mg} / \mathrm{g})=(12.7 * 663 \mathrm{~nm})-(2.69$ * $645 \mathrm{~nm}) * V / W * 10000$

Klorofil b $(\mathrm{mg} / \mathrm{g})=(22.91 * 645 \mathrm{~nm})-(4.68$ * $663 \mathrm{~nm}) * V / W * 10000$

Toplam Klorofil $=$ Klorofil a + Klorofil b

\section{Lipit peroksidasyonu}

Bitkilerde lipit peroksidasyonu, malondialdehit (MDA) içeriği olarak ifade edilmektedir. Bitkilerin alttan 3. yaprağından alınan $0.5 \mathrm{~g}$ yaprak örneği $10 \mathrm{ml} \% 0.1$ 'lik trikloroasetik asit (TCA) ile homojenize edildikten sonra homojenat 15000 rpm'de 5 dakika santrifüj edilmiștir. Santrifüj edilen örneğin berrak kısmından $1 \mathrm{ml}$ alınıp. üzerine $4 \mathrm{ml} \%$ 20'lik TCA içerisinde çözülmüș $\% 0.5^{\prime}$ lik tiobarbiturik asit (TBA) katılmıștır. Karıșım $95^{\circ} \mathrm{C}^{\prime}$ de 30 dakika bekletildikten sonra hızla buz banyosunda soğutulup 10000 rpm'de 10 dakika santrifüj yapıldıktan sonra berrak kısımdan 532 ve 600 nm dalga boyunda absorbansı belirlenmiș ve așağıdaki eșitlik ile malondialdehit (MDA) içeriği hesaplanmıștır (Jebara vd., 2005; Kabay ve Șensoy 2016; Kabay ve Șensoy 2017).

MDA (nmol ml-1) $=[(A 532-A 600) / 155000] * 10^{6}$

\section{Antioksidatif enzim analizleri}

Dondurulmuș 1 g yaprak örneği (bitkilerin alttan üçüncü yaprağı) $5 \mathrm{ml}$ soğuk $0.1 \mathrm{M} \mathrm{Na-}$ fosfat, $0.5 \mathrm{mM}$ Na-EDTA ve $1 \mathrm{mM}$ askorbik asit karıșımı (pH: 7.5) ile homojenize edildikten sonra. homojenat $4{ }^{\circ} C^{\prime}$ de 30 dakika 18000 rpm'de santrifüj edilmiștir. Bu șekilde hazırlanan homojenatta hemen askorbat peroksidaz (APX) aktivitesi belirlenmiștir. Katalaz (CAT) ve süperoksit dismutaz (SOD) aktivitelerinin belirlenmesi için 1 g dondurulmuș yaprak örneği $5 \mathrm{ml}$ soğuk $0.1 \mathrm{M}$ Na-fosfat, 0.5 mM Na-EDTA karıșımı (pH: 7.5) ile homojenize edildikten sonra. homojenat $4{ }^{\circ} \mathrm{C}$ 'de 30 dakika 18000 rpm' de santrifüj edilmiștir. Homojenatın bir kısmında hemen CAT aktivitesi belirlenmiș ve SOD belirlemesi için ekstrakt $-20^{\circ} \mathrm{C}^{\prime}$ de bekletilmiștir (Bağcı 2010; Jebara vd., 2005;: Kabay ve Șensoy 2016; Kabay ve Șensoy 2017).

\section{Katalaz (CAT) aktivitesi}

Katalaz aktivitesi, $240 \mathrm{~nm}$ dalga boyunda $\mathrm{H}_{2} \mathrm{O}_{2}$ nin kaybolmasının izlenmesi ile belirlenmiștir. Reaksiyon çözeltisi olarak $0.05 \mathrm{M}$ fosfat tamponu $\left(\mathrm{KH}_{2} \mathrm{PO}_{4}\right), 1.5 \mathrm{mM} \mathrm{H}_{2} \mathrm{O}_{2}$ karıșımı kullanılmıștır $(\mathrm{pH}$ : 7.0). $2.5 \mathrm{ml}$ reaksiyon çözeltisi ile $0.2 \mathrm{ml}$ bitki ekstraktı karıștırımıștır. Spektrofotometrede 240 $\mathrm{nm}$ dalga boyunda 0 . ve 60 . saniye okumaları alınmıștır. Reaksiyon 0.1 ml enzim ekstraktının ilavesi ile bașlatılmıștır. Değerlendirme 1 dakika içinde absorbansdaki değișim dikkate alınarak yapıımıștır (Jebara vd, 2005; Bağcı 2010; Kabay 2018b;).

\section{Süperoksit dismutaz (SOD) aktivitesi}

Nitroblue tetrazolium'un (NBT) 560 nm dalga boyunda inhibisyonu ile belirlenmiștir. Reaksiyon çözeltisi olarak $50 \mathrm{mMNa}$-fosfattamponu $\left(\mathrm{Na}_{2} \mathrm{HPO}_{4}\right.$ $\mathrm{x}_{2} \mathrm{O}_{2}$ ) $0.1 \mathrm{mM}$ Na- EDTA, $33 \mu \mathrm{M}$ NBT, $5 \mu \mathrm{M}$ riboflavin, $13 \mathrm{mM}$ methionin karıșımı kullanıımıștır (pH: 7.0). $2.5 \mathrm{ml}$ reaksiyon çözeltisi ile 0.1 veya $0.2 \mathrm{ml}$ bitki ekstraktı karıștırımıștır. Reaksiyon 25 ${ }^{\circ} C^{\prime}$ de $75 \mu \mathrm{mol} \mathrm{m}{ }^{-2} \mathrm{~s}^{-1}(40 \mathrm{~W})$ Ișık altında 10 dakika bekletilerek sağlanmıștır. Kontrol çözeltisi enzimsiz olarak karanlıkta aynı süre bekletilmiștir. Kontrol ve Reaksiyon çözeltisi 560 nm'de okunmuștur. SOD 
aktivitesi ünite olarak NBT'un \% 50'sini indirgeyen aktivite olarak belirlenmiștir (Jebara vd. 2005; Bağcı 2010; Kabay 2018b ).

\section{Askorbat peroksidaz (APX) aktivitesi}

Askorbat peroksidaz aktivitesi $290 \mathrm{~nm}$ dalga boyunda askorbik aside bağlı $\mathrm{H}_{2} \mathrm{O}_{2}$ 'nin indirgenmesi ölçülmüștür. Reaksiyon çözeltisi olarak $50 \mathrm{mM}$ fosfat tamponu $\left(\mathrm{KH}_{2} \mathrm{PO}_{4}\right), 0.5$ mM askorbik asit, $0.1 \mathrm{mM}$ EDTA, $1.5 \mathrm{mM} \mathrm{H}_{2} \mathrm{O}_{2}$ karıșımı kullanılmıștır (pH: 7.0). $3 \mathrm{ml}$ reaksiyon çözeltisi ile $0.1 \mathrm{ml}$ bitki ekstraktı karıștırılmıștır. Spektrofotometrede $290 \mathrm{~nm}$ dalga boyunda 0 . ve 60. saniye okumaları alınmıștır. Reaksiyon $0.1 \mathrm{ml}$ enzim ekstraktının ilavesi ile bașlatımıștır. Değerlendirme 1 dakika içinde absorbansdaki değișim dikkate alınarak yapılımıștır (Jebara vd. 2005; Bağcı 2010; Kabay ve Șensoy 2016; Kabay ve Șensoy 2017).

\section{İstatistik analiz}

Çalıșma tesadüf parsellerinde faktöriyel deneme desenine göre kurulmuștur. Kuraklık ve kontrol bitkilerinde stresin etkisinin belirlenmesi amacı ile elde edilen verilerin istatistiksel analizleri kullanılan deneme desenine göre (SAS 9.0) paket programında varyans analizine tabi tutulmuștur.

\section{BULGULAR VE TARTIȘMA}

Kuraklık stresinin bitkilerde besin maddesi içeriğini azalttığı bilinmektedir. Besin maddesi içerindeki azalma strese hassas olan bitkilerde daha fazladır. Kuraklık etkisindeki biber bitkilerinde potasyum (K) içeriğinin en fazla değiștiği bitki İnan 3363 biber çeșidi (kontrol: \% 3.670, kuraklık: \% 2.860, değișim oranı: \% 22.071) olurken, potasyum (K) içeriğinin en az değiștiği bitki ise Gölpınar genotipi (kontrol: \% 3.760 kuraklık: \% 3.480, değișim oranı: \% 7.447) olmuștur (Çizelge 1). Kalsiyum (Ca) içeriğinde ise en fazla düșüș İnan 3363 çeșidinde (kontrol: \% 2.670, kuraklık:
\% 1.150, değișim oranı: \% 56.929) olurken, en az değișim ise Gölpınar genotipi (kontrol: \% 2.330, kuraklık: \% 1.180, değișim oranı: \% 49.356) olmuștur (Çizelge 1). Magnezyum (Mg) içeriğinin en fazla değiștiği İnan 3363 çeșidinde (kontrol: \% 0.770, kuraklık: \% 0.280, değișim oranı: \% 63.636) olurken, en az değișim oranı Hilvan (kontrol: \% 0.680, kuraklık: \% 0.360, değișim oranı: \% 47.059) ve Gölpınar (kontrol: \% 0.640, kuraklık: \% 0.330, değișim oranı: \% 48.438) genotiplerinde olmuștur (Çizelge 1). Domateste yapılan çalıșmada kuraklık ve tuzlu șartlarda bitki gelișiminin olumsuz etkilendiği ve bitkideki $\mathrm{K}$ ile Ca oranlarının azaldığı bildirilmektedir (Ali ve Rab, 2017). Kuraklık stresi uygulanan fasulye genotiplerinin, $\mathrm{K}$ ve Ca içerikleri kuraklığa hassas çeșitlerde daha düșük çıkarken, kuraklığa tolerant genotiplerde ise kontrol bitkilerine yakın değerler çıktığı belirtilmektedir (Kabay ve Șensoy, 2016; Kabay ve Șensoy, 2017). Fasulyelerde su ve yüksek sıcaklık stresinin bitki gelișimini azalttığı tespit edilmiștir (Kacar vd., 2006; Gonzalez ve Pastenes, 2012). Kuraklık koșulları, hücrelerin bölünmesini ve büyümesini azaltıcı etkisi mineral madde alımının gerilemesine ve büyüme hızının düșmesine neden olabileceği vurgulanmıștır (Liu ve Stutzel, 2004).

Kuraklık stresinin biber genotiplerindeki klorofil içeriğinde meydana getirdiği değișimler ve elde edilen sonuçlar Çizelge 2'de verilmiștir. Klorofil a, klorofil b, klorofil a+b içerikleri, kuraklığa tolerant olan genotiplerde kuraklığa hassas olan genotiplere göre daha fazla değișmiștir. Klorofil a miktarları incelendiğinde (Çizelge 2) stres koșullarında en az düșüș \% 12.650'lik bir değișimle Gölpınar genotipinde görülmüștür. Klorofil a miktarı değișimi en fazla olan çeșit ise \% 52.787'lik bir kayıpla İnan 3363 çeșidi olmuștur. Kuraklık stresine maruz kalmıș biber genotiplerinde klorofil b açısından düșüșler gözlemlenmiștir. Klorofil b

Çizelge 1. Kuraklık stresindeki biber sürgünlerinde K, Ca ve Mg içeriklerindeki değișim (\%)

Table 1. Changes in the contents of $\mathrm{K}, \mathrm{Ca}$ and $\mathrm{Mg}$ in pepper shoots in drought stress (\%)

\begin{tabular}{ccrrrrrrrr}
\hline & K & \multicolumn{3}{c}{ Ca } & \multicolumn{3}{c}{ Mg } & \multicolumn{3}{c}{ Kuraklık \% değișimi } \\
\hline Genotipler & Kont. & Kurak. & Kont. & Kurak. & Kont. & Kurak. & K & Ca & Mg \\
Gölpınar & $3.760 \mathrm{a}$ & $3.480 \mathrm{a}$ & $2.330 \mathrm{~d}$ & $1.180 \mathrm{~b}$ & $0.640 \mathrm{c}$ & $0.330 \mathrm{~b}$ & -7.447 & -49.356 & -48.438 \\
Hilvan & $3.680 \mathrm{~b}$ & $3.140 \mathrm{c}$ & $2.540 \mathrm{c}$ & $1.270 \mathrm{a}$ & $0.680 \mathrm{~d}$ & $0.360 \mathrm{a}$ & -14.674 & -50.000 & -47.059 \\
İnan 3363 & $3.670 \mathrm{~b}$ & $2.860 \mathrm{~d}$ & $2.670 \mathrm{~b}$ & $1.150 \mathrm{~b}$ & $0.770 \mathrm{~b}$ & $0.280 \mathrm{c}$ & -22.071 & -56.929 & -63.636 \\
Osmanbey & $3.740 \mathrm{a}$ & $3.250 \mathrm{~b}$ & $2.750 \mathrm{a}$ & $1.240 \mathrm{a}$ & $0.850 \mathrm{a}$ & $0.370 \mathrm{a}$ & -13.102 & -54.909 & -56.471 \\
\hline
\end{tabular}


Çizelge 2. Kuraklık stresindeki biber genotiplerinin klorofil a, b ve a+b miktarındaki değișimleri (mg/g T.A)

Table 2. Changes in the chlorophyll $a, b$ and $a+b$ level of pepper genotypes at drought stress

\begin{tabular}{|c|c|c|c|c|c|c|c|c|c|}
\hline Genotip & $\begin{array}{l}\text { Kont. } \\
\text { KIf. a }\end{array}$ & $\begin{array}{l}\text { Kurak. } \\
\text { KIf. a }\end{array}$ & $\begin{array}{l}\text { Klf. a \% } \\
\text { değișimi }\end{array}$ & $\begin{array}{l}\text { Kont. } \\
\text { KIf. b }\end{array}$ & $\begin{array}{l}\text { Kurak. } \\
\text { KIf. b }\end{array}$ & $\begin{array}{l}\text { Klf. b \% } \\
\text { değișimi }\end{array}$ & $\begin{array}{c}\text { Kont. } \\
\text { KIf. a+b }\end{array}$ & $\begin{array}{l}\text { Kurak. } \\
\text { KIf. a+b }\end{array}$ & $\begin{array}{c}\text { Klf. a+b \% } \\
\text { değișimi }\end{array}$ \\
\hline Gölpınar & $1.660 \mathrm{~b}$ & 1.450 a & -12.650 & $2.650 \mathrm{C}$ & $2.050 \mathrm{c}$ & -22.642 & $4.310 c$ & $3.500 \mathrm{~b}$ & -18.794 \\
\hline Hilvan & $1.340 \mathrm{c}$ & $0.820 \mathrm{c}$ & -38.806 & $2.370 \mathrm{~d}$ & $1.450 \mathrm{~d}$ & -38.819 & $3.710 \mathrm{~d}$ & $2.270 \mathrm{~d}$ & -38.814 \\
\hline İnan 3363 & 3.050 a & 1.440 a & -52.787 & $3.460 \mathrm{~b}$ & 2.560 a & -26.012 & 6.510 a & 4.000 a & -38.556 \\
\hline Osmanbey & $1.670 \mathrm{~b}$ & $1.230 \mathrm{~b}$ & -26.347 & 3.750 a & $2.190 \mathrm{~b}$ & -41.600 & $5.430 \mathrm{~b}$ & $3.420 \mathrm{c}$ & -37.017 \\
\hline
\end{tabular}

içeriği açısından en az etkilenen genotip Gölpınar genotipi olmuștur. Klorofil b miktarı açısından en çok etkilenen ve en çok değișim gözlenen genotip ise Osmanbey genotipi olmuștur. Toplam klorofil değerlerinin değișim oranı \% 18.794 ile \% 38.814 arasında görülmektedir (Çizelge 2). Biberde 20 genotip'e su stresinin uygulandığı çalıșmada, kuraklık stresindeki genotiplerde klorofil içeriği, SOD ve CAT aktivitelerinde farklılıklar olduğu ve çalıșma sonunda kuraklığa dayanıklı, hassas ve orta derece dayanıklı olarak sınıflandırıldığı belirtilmektedir (Sahitya vd., 2018). Kuraklık stresine karșı hassas ve dayanıklı anaçlar üzerine așilı sırık domates bitkilerinde yapılan çalıșmada dayanıklı anaç kullanımı ile bitki boyu, ortalama gövde çapı, yaprak alanı, bitki yaș ve kuru ağırlıkları, toplam verim, pazarlanabilir verim, ortalama meyve ağırlığı, ortalama meyve büyüklüğü, klorofil ve karotenoid miktarı prolin miktarı, SOD, CAT, GR ve APX enzim aktivitesi değerlerinde artıș olduğu belirtilmektedir (Altunlu, 2011). Soya bitkilerine (Glycine max L.CV., A3935), kuraklık stresinin uygulandığı çalıșmada, MDA aktivitesinin arttığı ve klorofil miktarının da azaldığı belirtilmektedir (Kayabașı, 2011 ).

Calıșmamızda kuraklık stresine hassas olan İnan 3363 çeșidinde MDA değișimi daha fazla olurken, tolerans gösteren Hilvan genotipinde ise daha az değișim olmuștur. CAT içeriği kuraklık stresine hassas olan İnan 3363 çeșidinde kontrol 0.023 nmolg $^{-1}$ T.A iken, kuraklıkta 0.036 nmolg $^{-1}$ T.A olarak tespit edilmiștir. Kuraklık stresine tolerant olan Gölpınar genotipinde ise kontrol bitkilerindeki değer $0.011 \mathrm{nmol} \mathrm{g}^{-1}$ T.A iken, kuraklık stresinde ise $0.045 \mathrm{nmol} \mathrm{g}^{-1} \mathrm{~T}$.A olarak bulunmuștur (Çizelge 3). SOD ve APX aktivitesine bakıldığında ise kuraklık stresine hassas olan İnan 3363 ve kuraklık stresine tolerant olan Gölpınar biber bitkilerinde SOD ve APX aktivitesinde belirgin farklar olduğu görülmektedir (Çizelge 3).

Abiyotik streslerde reaktif oksijen türlerinin (ROS), bitkilerde strese karșı toleransın artırılmasında önemli rol oynadığı düșünülmektedir. Kuraklık stresinin iki tatlı sorgum bitkisinde antioksidan enzim sistemi üzerine etkisinin araștırılığı çalıșmada enzim aktivitelerinin artmasının kuraklığa toleransı arttırdığı belirtilmektedir (Guo vd., 2018). Șeftali yapraklarının antioksidan enzimlerin aktivitelerinin kuraklık stresi ile birlikte arttığı ve lipit peroksidasyonu ile fotosentezde azalmalar olduğu belirtilmektedir (Haider vd., 2018). Kuraklık stresinin zarar verici etkilerini azaltmak için çeșitli sulama kısıtlamaları olușturularak yetiștirilen lahana fidelerinde PGPR uygulamalarının, lipit peroksidasyonunu azaltarak lahana fidelerinin

Çizelge 3. Kuraklık stresindeki biber genotiplerinin MDA (nmol/g TA), CAT (mmol/g TA), SOD (unite/g TA) ve APX (mmol/g TA) aktivitelerindeki değișimleri

Table 3. Changes in the MDA (nmol/g TA), CAT (nmol/g TA), SOD (nmol/g TA) and APX (nmol/g TA) activity of pepper genotypes at drought stress

\begin{tabular}{ccccccccc}
\hline \multirow{2}{*}{ Genotip } & $\begin{array}{c}\text { Kont, } \\
\text { MDA }\end{array}$ & $\begin{array}{c}\text { Kurak. } \\
\text { MDA }\end{array}$ & $\begin{array}{c}\text { Kont, } \\
\text { CAT }\end{array}$ & $\begin{array}{c}\text { Kurak. } \\
\text { CAT }\end{array}$ & $\begin{array}{c}\text { Kont, } \\
\text { SOD }\end{array}$ & $\begin{array}{c}\text { Kurak. } \\
\text { SOD }\end{array}$ & $\begin{array}{c}\text { Kont, } \\
\text { APX }\end{array}$ & $\begin{array}{c}\text { Kurak. } \\
\text { APX }\end{array}$ \\
\hline Gölpınar & $10.190 \mathrm{ab}$ & $14.500 \mathrm{~b}$ & $0.011 \mathrm{c}$ & $0.045 \mathrm{a}$ & $0.940 \mathrm{~d}$ & $1.170 \mathrm{~d}$ & $0.180 \mathrm{c}$ & $0.340 \mathrm{~d}$ \\
Hilvan & $7.780 \mathrm{c}$ & $8.820 \mathrm{c}$ & $0.015 \mathrm{~b}$ & $0.027 \mathrm{c}$ & $1.230 \mathrm{~b}$ & $1.650 \mathrm{c}$ & $0.130 \mathrm{~d}$ & $0.370 \mathrm{c}$ \\
Inan 3363 & $8.460 \mathrm{bc}$ & $33.020 \mathrm{a}$ & $0.023 \mathrm{a}$ & $0.036 \mathrm{~b}$ & $1.080 \mathrm{c}$ & $2.670 \mathrm{a}$ & $0.570 \mathrm{a}$ & $0.650 \mathrm{a}$ \\
Osmanbey & $11.570 \mathrm{a}$ & $16.380 \mathrm{~b}$ & $0.012 \mathrm{c}$ & $0.022 \mathrm{~d}$ & $1.470 \mathrm{a}$ & $1.950 \mathrm{~b}$ & $0.340 \mathrm{~b}$ & $0.480 \mathrm{~b}$ \\
\hline
\end{tabular}


kuraklık stresine toleransını arttırdığı belirtilmiștir (Samancıoğlu vd., 2016). Yaș ve kuru ağırlıkları, toplam ve pazarlanabilir verim, ortalama meyve ağırlığı, ortalama meyve büyüklüğü, klorofil, karotenoid ve prolin miktarları ile SOD, CAT, GR ve APX enzim aktiviteleri değerleri artıș olduğu belirtilmektedir (Altunlu, 2011 ).

\section{SONUCLAR}

Kuraklık stresi biber bitkilerinde verim ve kaliteyi olumsuz etkilemektedir. Kuraklığa tolerant genotiplerin tespit edilmesi verim ve kalite kayıplarını önemli derecede önlemektedir. Yapılan çalıșmada kuraklık stresine hassas genotiplerde klorofil a, b, a+b, K, Ca, Mg miktarlarında azalma kuraklık stresine tolerant genotiplere göre daha fazla olduğu görülmüștür. Kuraklık stresindeki biber bitkilerindeki MDA, CAT, SOD ve APX aktivitelerinin arttığı görülmüstür. Sonuc olarak kuraklık stresinde uygulanan parametreler tolerant genotiplerin seçiminde uygun metotlar olduğu kanısındayız.

\section{TEȘEKKÜR}

Bu makale Van Yüzüncü Yıl Üniversitesi, Bilimsel Araștırma Projeleri Bașkanlığı tarafından desteklenen FYL-2017-6009 No'lu yüksek lisans tezinden üretilmiștir. Destekleri için teșekkür ederiz.

\section{KAYNAKLAR}

Amira MS, Qados A (2011). Effect of salt stress on plant growth and metabolism of bean plant Vicia faba (L.). Journal of The Saudi Society of Agricultural Sciences, 10:7-15.

Ali SG, Rab A (2017). The influence of salinity and drought stress on sodium. Potassium and proline content of Solanum Lycopersıcum L. Cv. Rio Grande. Pak. J. Bot. 49(1): 1-9. 2017.

Alp Y, Kabay T (2017). The effect of drought stress on plant development in some native and commercial tomato genotypes. Yüzüncü Yıl University Journal of Agricultural Sciences. 27(3): 387-395.

Altunlu H (2011). Așılamanın Domateste Kuraklık Stresine Etkileri (doktora tezi, Basılmamıș). Ege Üniversitesi, Fen Bilimleri Enstitüsü, Bornova, İzmir.

Bağcı E (2010). Nohut Çeșitlerinde kuraklıkğa bağlı oksidatif stresin fizyolojik ve biyokimyasal parametrelerle belirlenmesi (Doktora tezi basılmamıș). Ankara Üniversitesi Fen Bilimleri Fakültesi. s. 403 Ankara.

Gonzalez CJ, Pastenes C (2012). Water-stress-induced thermotolerance of photosynthesis in bean (Phaseolus vulgaris L.) plants: The possible involvement of lipid composition and xanthophyll cycle pigments. Environmental and Experimental Botany. 77: 127-140.
Guo YY, Tian SS, Liu SS, Wang WO, Sui N (2018). Energy dissipation and antioxidant enzyme system protect photosystem II of sweet sorghum under drought stress. Photosynthetica: 1-12.

Haider MS, Kurjogi MM, Khalil-ur-Rehman M, Pervez T, Songtao J, Fiaz M, Fang J (2018). Drought stress revealed physiological, biochemical and gene-expressional variations in 'Yoshihime'peach (Prunus Persica L.) cultivar. Journal of Plant Interactions, 13(1): 83-90.

Jebara S, Jebara M, Limam F, Aouani M E (2005). Changes in ascorbate peroxidase, catalase, guaiacol peroxidase and superoxide dismutase activities in common bean (Phaseolus vulgaris) nodules under salt stress. Journal of Plant Physiology. 162(8): 929-936.

Kabay T, Sensoy S (2016). Kuraklık Stresinin Bazı Fasulye Genotiplerinde Olușturduğu Enzim. Klorofil ve İyon Değișimleri. Yüzüncü Yı Üniversitesi Tarım Bilimleri Dergisi. 26(3): 380-395

Kabay T, Șensoy S (2017). Enzyme, Chlorophyll And Ion Changes In Some Common Bean Genotypes By High Temperature Stress. Ege Journal of Agricultural Research. 54(4): 429-437.

Kabay $T$ (2018a). Effects of Low Temperatures on Enzyme Activity, Chlorophyll and Ion Contents in Common Bean Genotypes. Applied Ecology and Environmental Research, 16(5): 7271-7287.

Kabay T. (2018b). effects of different potasium doses on Ion, chlorophyll and enzyme contents of drought sensitive bean plants. Fresenius Environmental Bulletin, 27(11): 77337738.

Kabay T, Ekincialp A, Erdinç C, Șensoy S (2018a). The Impact of Low temperatures on Plant Growth in Some Common Bean Genotypes. Fresenius Environmental Bulletin. 27(12a): 8715-8722.

Kabay T, Alp Y, Șensoy S (2018b). Effect of Vermicompost Application on Some Plant Characteristics In Lettuce (Lactuca Sativa L.). Fresenius Environmental Bulletin.27(12b): 9942-9948

Kabay T (2019). Effects of Different Potassium Doses On Development of High Temperature-Sensiti ve Bean Plants. Feb-Fresenius Environmental Bulletin, 28(1) :320-325.

Kacar B, Katkat B, Öztürk Ș (2006). Bitki Fizyolojisi. Nobel Yayım Dağııım. 2.493-533.

Kayabașı S (2011). Kuraklık Stresinde Yetiștirilen Soyada Bazı Fizyolojik Parametreler İle Prolin Birikiminin Arasțtıılması lyüksek lisans tezi). Harran Üniversitesi Fen Bilimleri Enstitüsü, Șanlıurfa.

Kușvuran Ș (2010). Kavunlarda Kuraklık ve Tuzluluğa Toleranslı Fizyolojik Mekanizmaları Arasındaki Bağlantılar (Doktora tezi. basılmamıș). Çukurova Üniversitesi. Fen Bilimleri Enstitüsü s. 356. Adana.

Lichtenthaler HK, Wellburn AR (1983). Determinations of total careteonids and chlorophylls a and b of leaf extracts in different solvents. Biomchem. Soc. Transac. 11:591-592.

Liu F, Stutzel H (2004). Biomass partitioning, specific leaf area and water use efficiencyof vegetable amaranth (Amaranthusspp.) in response to drought stress. Scientia Horticulturae, 102 (1): 15-27 
Özfidaner M, Șapolyo D, Topaloğlu F (2018). Seyhan Havzası Akım Verilerinin Hidrolojik Kuraklık Analizi. Toprak Su Dergisi. 7(1): 57-64.

Özkan CF, Asri FÖ, Demirtaș El, Arı N (2013). Örtüaltı Biber Yetiștiriciliğinde Organik ve Kimyasal Gübre Uygulamalarının Bitkinin Beslenme Durumu ve Bitki Gelișimi Üzerine Etkileri Toprak Su Dergisi, Cilt 2 Sayı 2 (96-101).

Sahitya UL, Krishna MSR, Deepthi R, Prasad GS, Kasim D (2018). Seed Antioxidants Interplay with Drought Stress Tolerance Indices in Chilli (Capsicum annuum L.) Seedlings. Bio Med research international. https://doi. org/10.1155/2018/1605096

Samancıoğlu A, Yıldırım E, Șahin Ü (2016). Bitki Gelișimini Teșvik Eden Rizobakteri Uygulamalarının Farkı Sulama Seviyelerinde Yetiștirilen Lahanada Fide Gelișimi, Bazı Fizyolojik ve Biyokimyasal Özellikler Üzerine Etkisi. Kahramanmaraș Sütçü İmam Üniversitesi Doğa Bilimleri Dergisi, 19(3): 332-338.
Sanchez-Rodriguez E, Rubio-Wilhelmi M, Cervilla LM, Blasco B, Rios JJ, Rosales MA, Ruiz JM (2010). Genotypic differences in some physiological parameters symptomatic for oxidative stress under moderate drought in tomato plants. Plant Science, 178(1): 30-40.

Zengin FK (2007). Fasulye Fidelerinin (Phaseolus vulgaris L. cv. Strike) Pigment lçeriği Üzerine Bazı Ağır Metallerin Etkileri. KSÜ Fen ve Mühendislik Dergisi. 10-2 Kahramanmaraș.

Zushi K, Kajiwara S, Matsuzoe N (2012). Chlorophyll A Fluorescence OJIP transient as a tool to characterize and evaluate response to heat and chilling stres in tomato leaf and fruit. Scientia Horticulturae. 14 : 39-46. 